論文

\title{
水平直線光源下に置いた水平円板による影の特性
}

\author{
専門会員 藤原 義 輝* 専門会員大谷 義 彥*
}

\section{Characteristics of the Shadow Produced by a Horizontal Disk \\ Setting under a Horizontal Linear Light Source.}

\author{
Yoshiteru Fujiwara (Fellow Member) \\ Yoshihiko Ohtani (Fellow Member)
}

(Department of Electrical Engineering, College of Industrial Technology, Nihon University)

\begin{abstract}
The method of calculating the direct illuminance and the shadow factor in the shadow which is produced on the illuminated plane by a horizontal disk under the condition that a diffused linear light source is kept in a horizontal or vertical position was discussed in our previous report.

In this paper we describe and discuss the results of some calculations on the shadow factor when the diffused linear light source is kept in a horizontal position.

First, with the light source fixed, the shadow factor on the illuminated plane under various positions of a disk is calculated.

Then, with the disk fixed, variations of the shadow factor at the illuminated point which is directly under a disk when the light source is moved are calculated.

From these results, the methods of predicting the shadow zone and the suitable position of a light source to make the shadow as little as possible can be obtained.
\end{abstract}

\section{1. 緒言}

光源と被照面間に物体があるとき，被照面上に生ずる 影は，作業を行なう場合の手暗がりなどとしてよく経験 するが，このような影は作業に際してじゃまなものであ り，その影響をなるべく少なくするためにも，照明設計 の一要素1 として十分考慮すべき問題と考えられる.し かしながら影は, 光源, 物体の形状ならびに相互の位置 関係によって複雑に変化し, その解明は十分になされて いないのが現状である.

* 日本大学生産工学部電気工学科

昭和49年照明学会全国大会, 昭和50年電気四学会中国支部連合大会に て発表.
筆者らはこのような影に興味をもち，その究明の第一 段階として, 直線光源が水平また怡鎮にある場合, 水 平円板によって, 被照面上に生ずる影の中の直射照度の 計算方法を求め, さきに発表した2). そしてその後, こ の計算方法により, 直線光源と水平円板によって生ずる 影の状態について種々検討を試みてきたが3)4)，今回は これらのらち, 光源が水平直線光源の場合についてまと めたので報告する.

まず，光源を固定して水平円板を各種位置に設定した ときの被照面上における影の状態, ついで水平円板の位 置を一定として光源を動かした場合の, 水平円板直下に 定めた被照面上における影の変化について求めた。ささ にこれらの結果から影の生ずる範囲の予測や, 影の影響 
を受けないよらな光源の配置などを知るための手がかり を得た。

\section{2. 影 の 計 算}

\section{1 計算方法の概要 ${ }^{2)}$}

影は，光源と被照面間にある物体によってさえぎられ て，本来あるべき照度が失われてしまう現象である。し たがって，影の中のある点より光源をながめたとすれ ば，他の物体によって光源の一部，または全部が隠され ているはずである，全部が隠されていれば，その点には 本影が生じているのであり直射照度はゼロであるまた 一部が隠されているのは，半影でありその点の直射照度 を計算で求めるには，その点から実際に見ることのでき る光源の部分だけを計算上の光源とすればよい

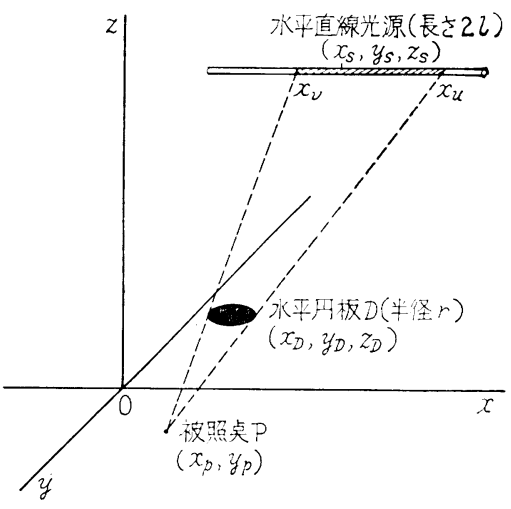

図 1 光源と円板の位置関保

そこで, 本論文で述べる水平直線光源と水平円板の場 合について考えてみる. 図 1 に示すような直角㭫標系 $(x, y, z)$ に拈いて, 長さ $2 l$ の払散性直線光源を $x$ 朝 と平行に設置し，その中央の座標を $\left(x_{S}, y_{S}, z_{S}\right)$ とす る. 半径 $r$ の円板 $\mathrm{D}$ を水平㯰き，その中心座標を $\left(x_{D}\right.$, $\left.y_{D}, z_{D}\right)$ とする. また $x y$ 平面を被照面とし，面内の 任意の被照点 $\mathrm{P}$ の座慓を $\left(x_{p}, y_{p}, 0\right)$ とする。そして

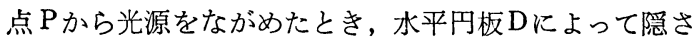
れる部分の境界の $x$ 座標を $x_{u}, x_{v}$ とすると，幾何学的 に次のように求められる.

$$
\begin{aligned}
& x_{u}, x_{v}=\frac{z_{S}}{z_{D}}\left[ \pm \sqrt{r^{2}-\left\{\frac{\left(z_{S}-z_{D}\right) y_{p}-z_{D} y_{S}}{z_{S}}-y_{D}\right\}^{2}}\right. \\
& \left.+x_{D}-\frac{\left(z_{S}-z_{D}\right) x_{p}}{z_{S}}\right]
\end{aligned}
$$

ただし，根号の中は正の場合たけとし，また

$$
x_{S}+l>x_{u}>x_{v}>x_{S}-l
$$

とする.

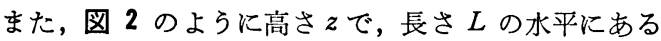
抁散性直線光源において, その一端直下から光源の正射 影に垂直に $y$ だけ隔った点に打ける, 水平面照度 $E_{L}$ は 次式から計算できる5.

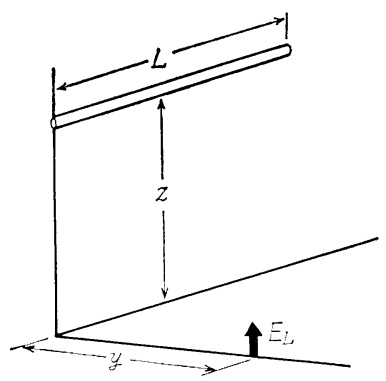

图 2 水平汇ある完全扗散直粽光源に よる水平面㬎度

$$
\begin{aligned}
E_{L}= & \frac{I z}{2 \sqrt{z^{2}+y^{2}}}\left\{\frac{L}{z^{2}+y^{2}+L^{2}}\right. \\
& \left.+\frac{1}{\sqrt{z^{2}+y^{2}}} \tan ^{-1} \frac{L}{\sqrt{z^{2}+y^{2}}}\right\}
\end{aligned}
$$

ただし，I は光源軸に垂直な方向の光源単位長さあた りの光度である.

したがって図 1 において，光源およびその延長線上に 扣いて被照点の $x$ 座漂 $x_{p}$ を基準として $\left(x_{S}+l\right), x_{u}$ ， $x_{v},\left(x_{S}-l\right)$ までの長さの直線光源を想定し, 各々より 得られる照度值の和または差により，実際に見える部分 に対する照度を求めれば，これが影の中の被照点に打け る直射照度となる。

\section{2 影 の 深さ}

影の状態を定量的に表わすものとして,「影の深さ」677) が提唱されて和りこれは「影によって失われた照度と 影のないときの照度との比」で定義されている。すなわ ち，影の深さを $S$ ，影の中の照度を $E_{0}$ ，そして影のな いときの照度を $E$ とすると

$$
S=\frac{E-E_{0}}{E}
$$

で与えられる. したがって，本影の場合は $S=1.0$ ，半 影で $1.0>S>0.0$, 影のない場合 $S=0.0$ となり影の生 じている程度がはっきりとわかる。

\section{3 影 の 状 態}

長さ $2 l=1.0$ の光源の座標が $\left(x_{S}, y_{S}, z_{S}\right)=(0.0$, $0.0,1.5)$ で, 半径 $r=0.1$ の円板の座標を $\left(x_{D}, y_{D}\right.$, $\left.z_{D}\right)=(0.2,0.0,0.5)$ ，および $(0.0,0.2,0.2)$ と した場合の計算結果例を図 3，図 4 に示した。いずれ も(a)は被照面上における等照度曲線，(b)は同じく等しい 影の深さ曲線，そして(c)は $x$ 軸上または $y$ 軸上における 照度曲線と影の深さ曲線である. 図 3 は円板が $x$ 軸上に ある場合，図 4 は $y$ 軸上にあり本影の生じている場合の 例である.

円板がなく影が生じていなければ，等照度曲線は原点 を中心にした同心円に近い形となるから，影の生じてい る場合の影の範囲や程度は，等照度曲線の乱れより推察 


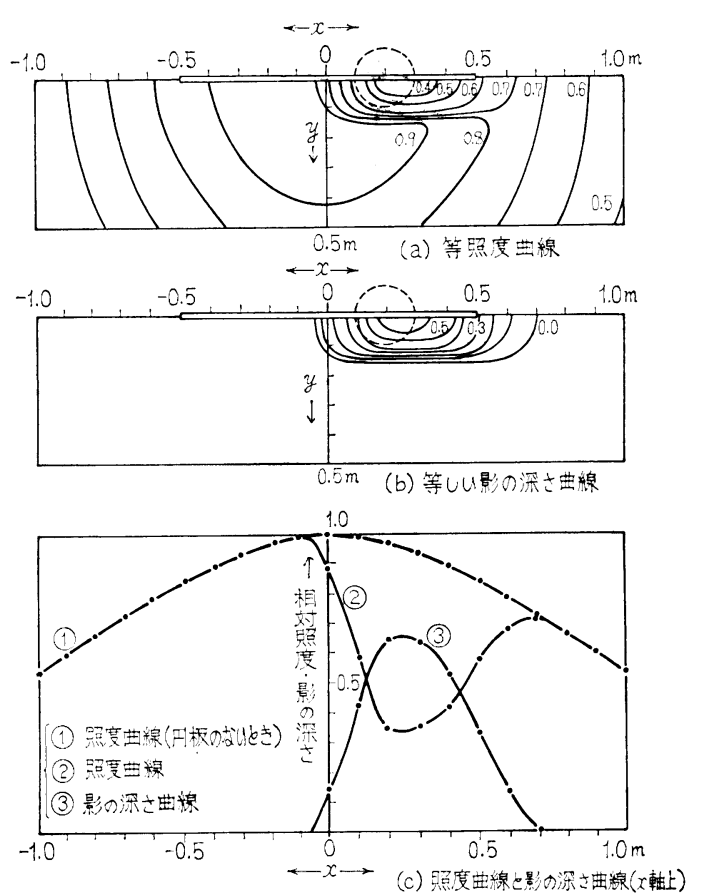

図 $3\left(x_{S}, y_{S}, z_{S}\right)=(0.0,0.0,1.5),\left(x_{D}, y_{D}, z_{D}\right)$ $=(0.2,0.0,0.5)$ に打计る結果例
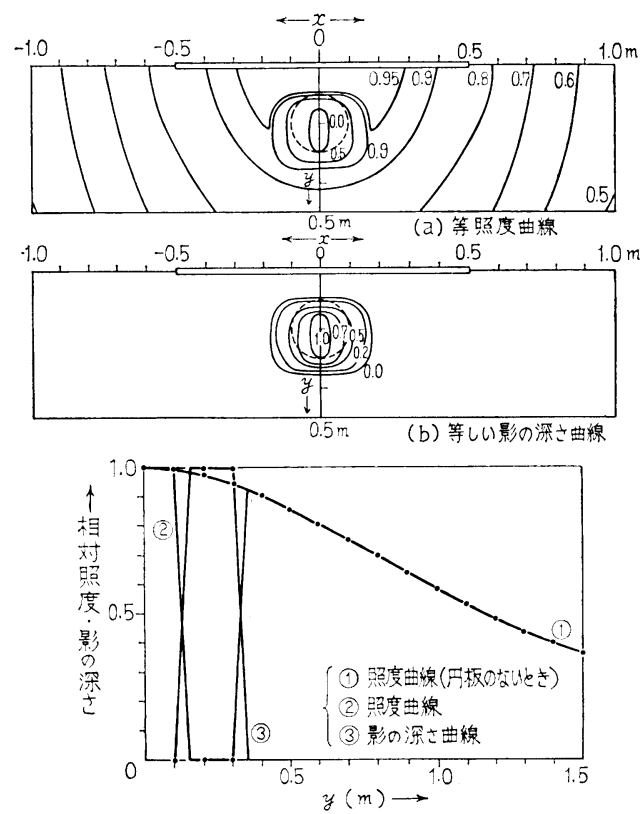

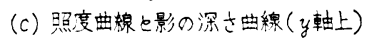

图 $4\left(x_{S}, y_{S}, z_{S}\right)=(0.0,0.0,1.5),\left(x_{D}, y_{D}, z_{D}\right)$ $=(0.0,0.2,0.2)$ における結果例

することができる．また等しい影の深さ曲線なら，本 影，半影そして影のない部分の区別や半影の程度をはっ さり知ることができて便利である. しかし本論文では， 光源や円板の位置の変化に対する影の状態を比較するの
で，次章以後は， $x$ 軸をたは $y$ 軸上に怙ける影の深さ曲 線によることとした。

\section{3. 光源の位置がー定の場合}

本章では, 2.3 の場合と同様に, 長さ $2 l=1.0$ の光源 を原点上高さ $1.5 \mathrm{~m}$ の位置に， $x$ 軸と平行となるように 水平に設定し，円板の位置を変えた場合の被照面上の影 について求めた.

\section{1 影の深さ曲線の比較}

円板を $x$ 軸上の各位置においた場合の， $x$ 軸における 影の深さ曲線を図 5 に，y軸上の各位置においた場合 の $y$ 軸に拈けるるのを図 6 に示す.
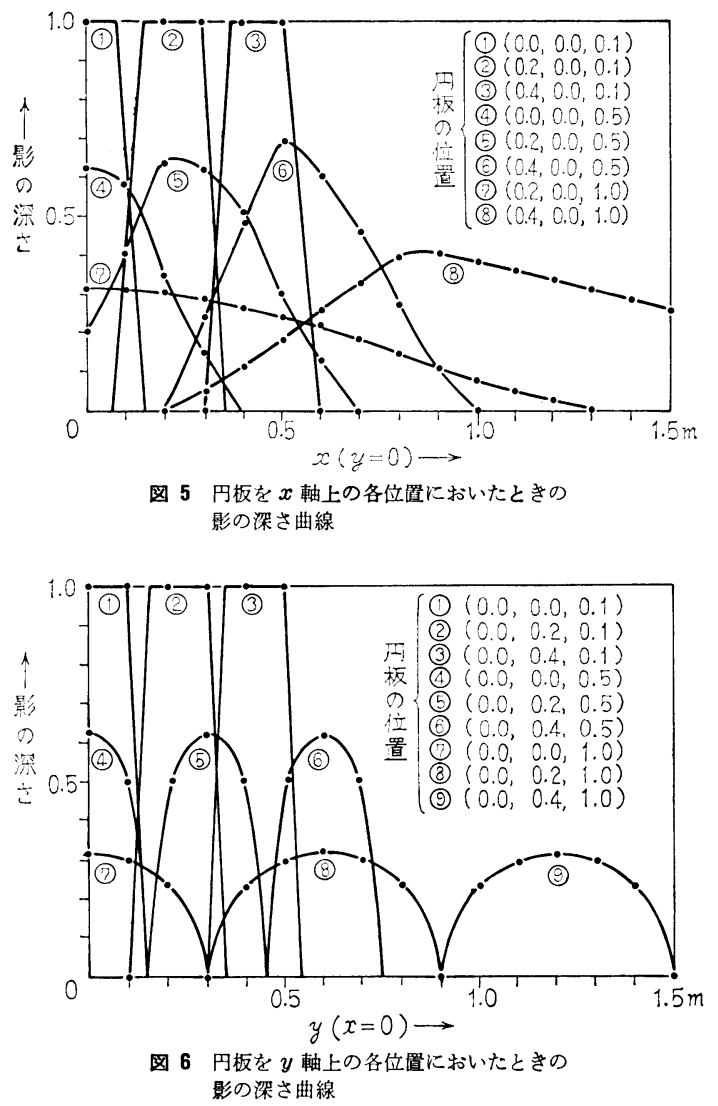

円板が低い位置にあると，影の深さが 1.0 すなわち本 影の生ずるほどになるが，影の範囲は狭く逆に円板を高 くすると影の深さは小さくなるが，影の範囲は広くなっ ている．影のひろがりは $y$ 軸方向より $x$ 軸方向のほうが 大きく，光源の形に影響されていることがわかる.

次に，円板の高さを一定として $x$ 軸方向へ動かした場 合を考えると，原点から遠ざかると影の深さがやや大き くなる程度で影の範囲には変化がなく, また $y$ 軸方向へ 円板を動かしたとしても，影の生ずる場所が移動するだ けで影の深さ曲線の形には全く変わりがない。 
これらの理由としては, 円板が高くなると影の中の被 照点から光源をながめたとき，円板によって隱される部 分は少なくなり，また円板を低くすると被照点からみた 円板の立体角が大きくなり，したがって光源の隠される 部分が大きくなるからであるままた円板の高さを変えず 飞 $x$ 方向または $y$ 方向へ動かした場合は, 円板の移動に 伴って影の生ずる場所も動くので，影の中の被照点から 光源をみた場合, 光源の全長に対する隠される部分の割 合が， $x$ 軸方向の場合あまり変化しないし，y軸方向で は全く変わらないからである.

\section{2 影の深さの最大值}

図 5 , 図 6 亿示したような曲線を基にして, 円板の各 位置に対する影の深さの最大值を求めて, 等しい影の深 さの最大值曲線としたのが図 7 (a)，(b)である. (a) は $x-z$ 軸を含む面, (b) は $y-z$ 軸を含む面についてのもの である.

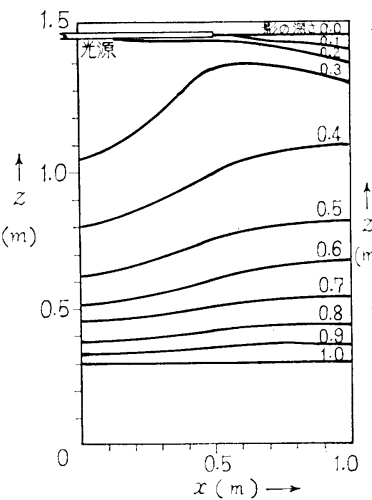

(a) $x-z$ 平面

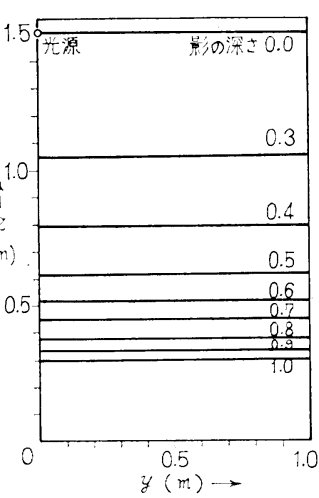

(b) $y-z$ 平面
因 7 等しい影の深さの最大傎曲線

光源と被照面間に円板があれば何らかの影が生じ，ま たこの場合では, 円板の高さが $0.3 \mathrm{~m}$ 以下では必ず本影 となることがわかる．また前節でも述べたような，円板 の高さを変えたり， $x$ 方向または $y$ 方向へ動かしたとき の影の深さの変化が一目瞭然である.

\section{3 影の生ずる範囲}

図 5 , 図6に示したような曲線から，円板の位置を動 かしたとさの $x$ 軸をたは， $y$ 軸上に打ける影の範田の変 化をグラフに表わしたのが図 8，図9である. 図8(a)は 円板を $x_{D}=0.2$ として高さを変えた場合，同(b)は $z_{D}=$ 0.1 として $x$ 軸方向へ変えた場合, 図 $9(\mathrm{a})$ は $y_{D}=0.0$ と して高さを変えた場合，そして同(b)は $z_{D}=0.2$ として $y$ 軸方向へ变えた場合のものである. 四中 $x_{a}, x_{d}, y_{e}$, $y_{f}$ は影のない部分と半影の部分との境界となる座標, そして $x_{b}, x_{c}$ は, 半影と本影との境界となる座標を示 している.

$x, y$ 両軸上共, 円板が 高くなると影の範囲が急速に
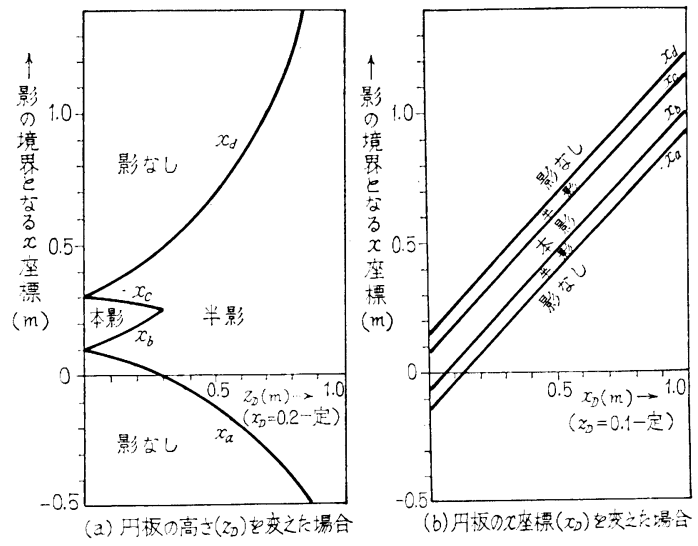

図 $8 x$ 軸上における影の境界の変化

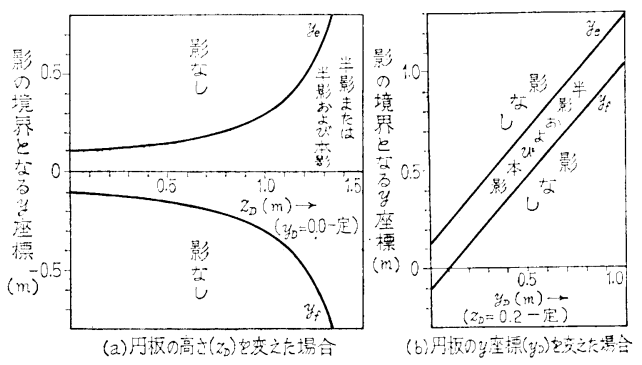

図 $9 y$ 軸上における砇の境界の変化

ひろがり，曲線は光源の高さ $z_{S}=1.5$ を漸近線としてい ることがわかる(図 8 , 図 9 の(a)). また， $x$ 軸上に拉 ける本影の範囲は円板の高さ $z_{D}=0.0$ で最大で, 円板の 直径 $2 r=0.2$ と同じであるが, 高くなるとだんだんと狭 くなり $z_{D}=0.3$ で本影は生じなくなる（因 8 ).

一方, 円板の高さを一定として $x$ または $y$ 方向に動か しても影の範囲には全く変わりなく, ただ生じる位置が 動くだけである(図 8 , 図 9 の(b)).

\section{4 影の範囲の予測}

前節で述べた円板の位直と, 影の生ずる範囲との関係 は, 幾何学的な方法によってその概略を予測することが できる.すなわち，図 10 の立面図に扣いて光源の両端 から円板の両端に引いた 4 本の直線の延長が $x$ 軸と交わ る点を $x_{a}, x_{b}, x_{c}$ そして $x_{d}$ とし, 側面図においても 光源より円板の両端を通る 2 直線が， $y$ 軸と交わる点を $y_{e}, y_{f}$ とすると各々は次式により得られる.

$$
\begin{aligned}
& x_{a}=\left\{z_{S}\left(x_{D}-r\right)-z_{D} l\right\} /\left(z_{S}-z_{D}\right) \cdots \\
& x_{b}=\left\{z_{S}\left(x_{D}-r\right)+z_{D} l\right\} /\left(z_{S}-z_{D}\right) \cdots \\
& x_{c}=\left\{z_{S}\left(x_{D}+r\right)-z_{D} l\right\} /\left(z_{S}-z_{D}\right) \cdots \\
& x_{d}=\left\{z_{S}\left(x_{D}+r\right)+z_{D} l\right\} /\left(z_{S}-z_{D}\right) \cdots \\
& y_{e}=z_{S}\left(y_{D}+r\right) /\left(z_{S}-z_{D}\right) \\
& y_{f}=z_{S}\left(y_{D}-r\right) /\left(z_{S}-z_{D}\right) \cdots \cdots \cdots \cdots \cdots \cdots \cdots \cdots
\end{aligned}
$$

影が生じるためには $z_{D}>z_{S}$ の条件が必要であり, 本

Vol. 61 No. 2 


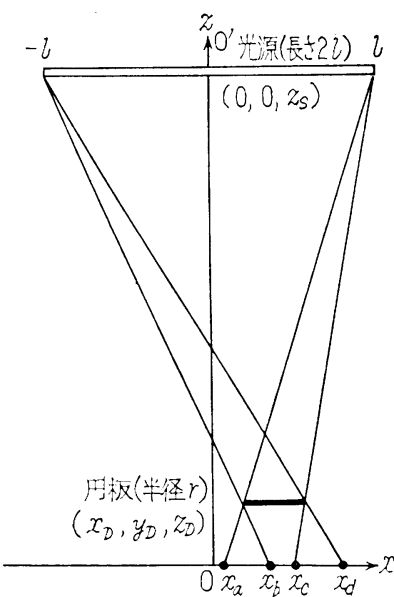

立面园

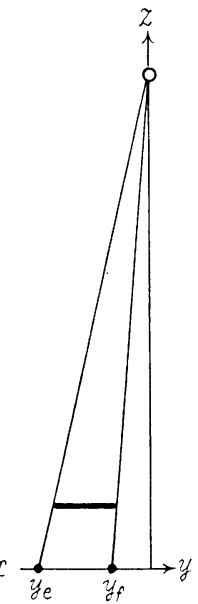

側面図
図10 影の生ずる管柬

影は $x_{b} \leqq x_{c}$ の場合にだけ生ずることから， $z_{D} \leqq z_{S} r / l$ の 条件が得られる. また $x, y$ 軸上に却ける影の範囲は $\left(x_{d}-x_{a}\right)=2\left(z_{S} r+z_{D} l\right) /\left(z_{S}-z_{D}\right), \quad\left(y_{e}-y_{f}\right)=2 z_{S} r /$ $\left(z_{S}-z_{D}\right)$, そして $x$ 軸上の本影の簌囲は $\left(x_{c}-x_{b}\right)=2$ $\left(z_{S} r-z_{D} l\right) /\left(z_{S}-z_{D}\right)$ となることから, これらすべては 光源および円板の $x, y$ 夾標すなわち $x_{S}, y_{S}, x_{D}$ そ して $y_{D}$ に関係のないことがわかる.このことは図 8 ， 因 9 の(b)によっても明らかである.

光源と円板の位置が定まれば, 影は $x=x_{a}, x=x_{d}$, $y=y_{e}, y=y_{f}$ によって囲まれる矩形部分に生じ, この うち $x=x_{b}$ から $x=x_{c}$ までは, 本影の含まれる部分と して予測できる. 図 11 は円板を $\left(x_{D}, y_{D}, z_{D}\right)=(0.4$, $0.2 ， 0.2)$ とした場合の等しい影の深さ曲線と, 上述の 方法により求めた矩形の影の範囲とを比較したものであ る. 予測した範囲内に影の深さ 0.0 , および 1.0 の曲線 が扣さまっていることがわかる。

\section{4. 光源の位置を変化させた場合}

ここでは, 円板の位置を原点上高さ $0.3 \mathrm{~m}$ と一定にし て, 光源の位置を変えたときの原点における影の深さの 変化について述べる。すなわち，実際の作業状態におい

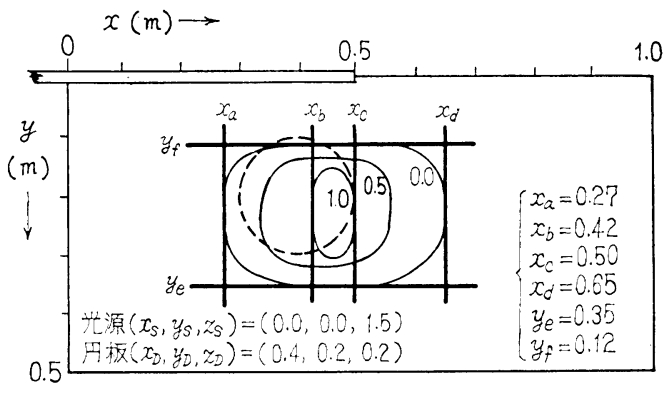

図 11 影の生ずる簌囲の予測と等しい影の深さ曲線
ても，光源の位置を動かして，影の生しない最良の照明 条件を見つけるようなこともあり，水平円板を作業者の 頭部に見立てて，その直下に抢兴影の变化を求めてみ た。

\section{1 影の深さ曲線の比較}

光源の位置を $x$ 軸上で高さを変えた場合 $(\mathrm{a})$, 高さを一 定として $x$ 軸方向に動かした場合(b)，y軸上で高さを変 えた場合(c)，そして高さを一定として $y$ 軸方向に動かし た場合(d)の 4 と招りについて，原点上の影の深さの変化 を図 12 に示した。

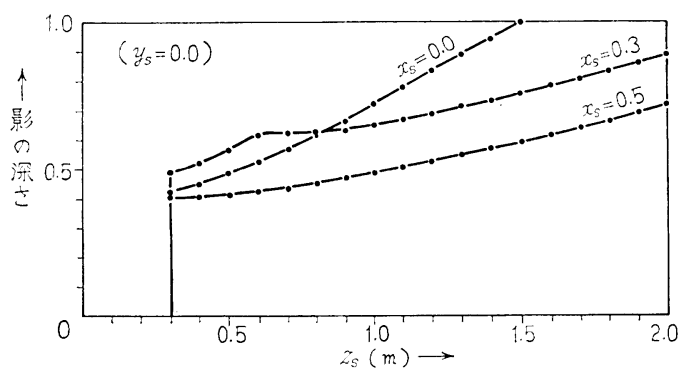

(a) $x$ 檕上で高ざ夜之た場合

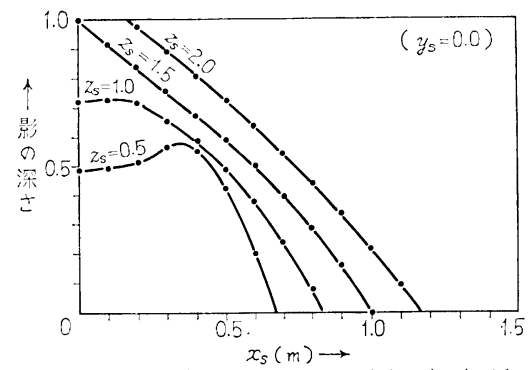

（b）高さを一定としてx方向长变之た場合

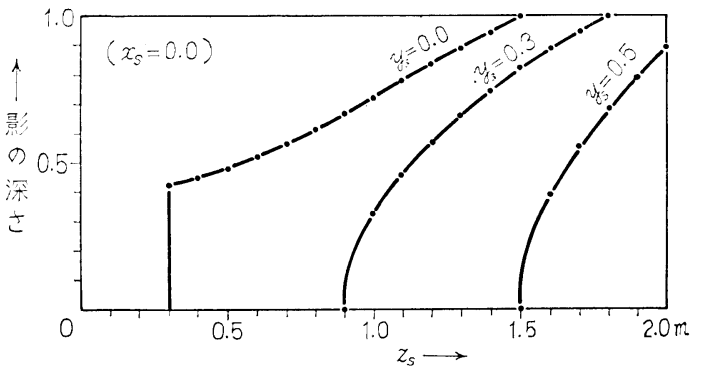

（c）y軸上で高させ夜之た場合

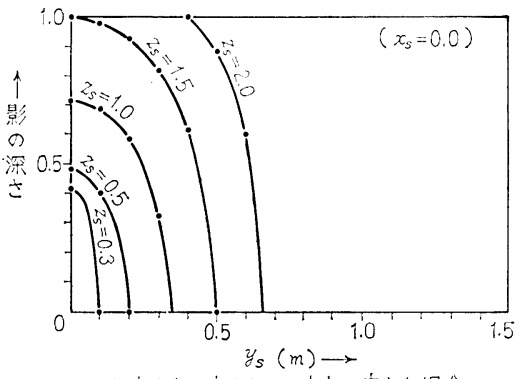

(d) 高さを一定としてy方向心交之た場合

図 12 光源の位置に対する影の深さ 
光源を高くする汪と影の深さは大きくなり，また光源 を原点より遠ざけると逆に影がなくなっている。これは 光源が高くなると影の生ずる位置が円板直下，すなわち 原点へと近づいてきて，遂には原点より円板を見込む立 体角の中に光源がはいってしまい本影となり，一方，光 源を原点から遠ざけると, 影の生ずる位置がだんだんと 円板直下より遠いところとなって，原点上には影ができ なくなるからである.

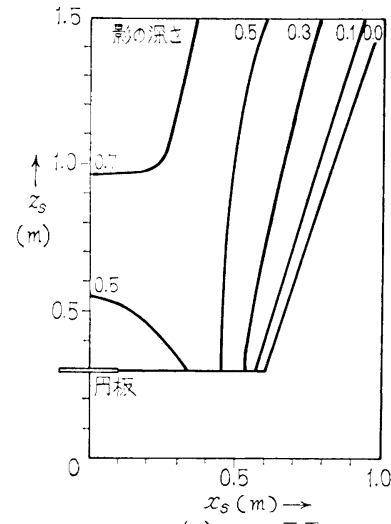

(a) $x-z$ 平面

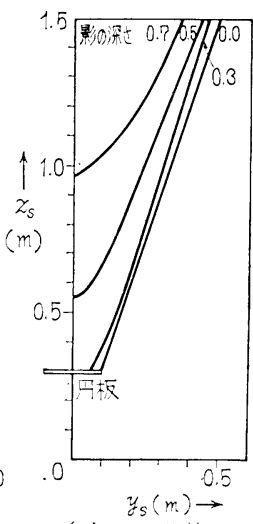

(b) $y-z$ 综
図 13 光源の位圈汶対する原点上の等しい影の深さ曲線

\section{2 光源の位置と影の深さ}

光源の位置に刘する原点上の影の深さを示す等しい影 の深さ曲線としたのが図 13 である. (a) は $x-y$ 軸を含 む面，(b) は $y-z$ 軸を含む面についてのものである.こ れらにより，影の少ない作業に適した光源の位置を見い 出すことがでさる. しかし，影が生じていなくても光源 があまり遠すぎると, 被照点の照度が十分得られなくな るので, 影の深さだけで判断することは危険である.

\section{3 影 の 範 囲}

3.4 で述べた影の生ずる範用の境界点は, 光源の位置 を変化させた場合についても同じように求めることがで きる.すなわち，式(4)〜(9)に示したような $x$ 軸または $y$ 軸上の影の境界点を，ここでは $x_{a}^{\prime}, x_{b}^{\prime}, x_{c}^{\prime}, x_{d}^{\prime}, y_{e}^{\prime}$ そして $y_{f}^{\prime}$ とすると,

$$
\begin{aligned}
& x_{a}^{\prime}=\left\{z_{S} r+z_{D}\left(x_{S}+l\right)\right\} /\left(z_{D}-z_{S}\right) \cdots \cdots \cdots \cdots(10) \\
& x_{b}^{\prime}=\left\{z_{S} r+z_{D}\left(x_{S}-l\right)\right\} /\left(z_{D}-z_{S}\right) \cdots \cdots \cdots \cdots(11) \\
& x_{c}^{\prime}=\left\{z_{S} r-z_{D}\left(x_{S}+l\right)\right\} /\left(z_{S}-z_{D}\right) \cdots \cdots \cdots \cdots(12) \\
& x_{d}^{\prime}=\left\{z_{S} r-z_{D}\left(x_{S}-l\right)\right\} /\left(z_{S}-z_{D}\right) \cdots \cdots \cdots \cdots(13) \\
& y_{e}^{\prime}=\left(z_{S} r-z_{D} y_{S}\right) /\left(z_{S}-z_{D}\right) \cdots \cdots \cdots \cdots \cdots \cdots(14) \\
& y_{f}^{\prime}=\left(z_{S} r+z_{D} y_{S}\right) /\left(z_{D}-z_{S}\right) \cdots \cdots \cdots \cdots \cdots \cdots(15)
\end{aligned}
$$

として得られるが, $z_{S}>z_{D}$ で影が生じ, $z_{S} \geqq z_{D} l / r$ で本 影が生じ, 影の生ずる範用が光源および円板の高さだけ に関係することなどは，やはり 3.4 の場合と同様であ る.

Vol. 61 No. 2

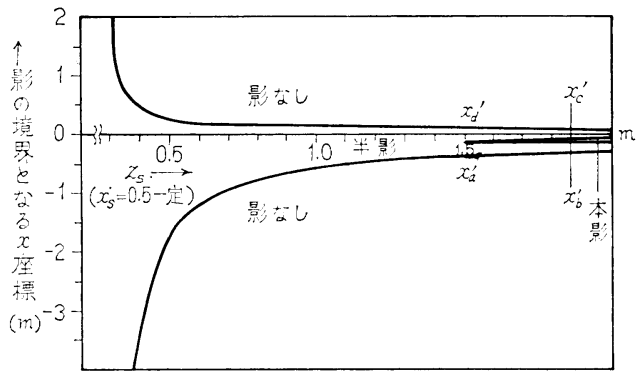

图 14 光源の高さを变えたときの影の境界の変化

光源を $x_{S}=0.5$ としたときの, 高さ $z_{S}$ と $x_{a}^{\prime}, x_{b}^{\prime}, x_{c}^{\prime}$ そして $x_{d}^{\prime}$ との関係を一例として図 14 に示す.影の範 囲は光源が低くなるほどひろがっており, 円板と同じ高 さ（ここでは $z_{D}=0.3 ）$ になると，無限に影が生じてい る状態となる．なた本影は $z_{S}=1.5$ 以上から生ずること になり，光源を高くすると影の範囲は狭くなるが，本影 の占める割合は大きくなっていることを示している.

影の生ずる範囲も同様に, $x=x_{a}^{\prime}, x=x_{d}^{\prime}, y=y_{e}^{\prime}$ そ して $y=y_{f}^{\prime}$ に囲まれる矩形部分と， $x=x_{b}^{\prime}$ から $x=x_{c}^{\prime}$ までの本影の部分として予測することができる.

\section{5. 結言}

水平直線光源と水平円板の組み合わせにより, 被照面 上に生ずる影の状態を，「影の深さ」により定量的に求 め検討した.

影の状態は, 光源, 円板および被照点の位置関係によ って複雑な変化をするが, ある程度の規則性もあるので 手に㧤えないといらほどでもない，影が生じた場合，そ の位置, 範囲および程度が問題となると思われるが, 位 置や䇺囲については，3.4 4.3 で述べたように幾何学 的な予測が可能であり, 影の程度を知るには図 7 や図 13 が手がかりとして役に立つであろう。

しかし, 被照点に影さえ生じていなければ照明状態が 良効であるとはいえず, 被照面上の平均照度や均せい度 なども当然考慮しなければならない。そこで現在は, こ れらのことも含めてさらに検討中であり ${ }^{8)}$, その詳細に ついては次の機会に報告したいと思っている. また, 光 源についても直線が複数存在する場合, あるいは面光源 の場合など,より実際的な場面を想定し, 影の問題を考 えていくつもりでいる.

\section{参 考 文献}

(1) P. Moon and D. Spencer: Lighting Design 邦 訳藤原・斉藤（昭 30） 203

（2）藤原・大谷：照学誌 58-2 (昭 49) 49〜 57

（3）藤原・大谷：昭 49 照学全国大会予稿 53 
(4) 大谷：昭 50 電四学中国支部連大予稿 20

（5）たとえば藤原ほか：照明・電熱（昭 38）130〜139

（6）山内・中路：照明・電灯および電熱（昭 11） 158

(7) K. Norden: Shadow and Diffusion in Illumi- nating Engineering (1948) 4

(8) 大谷：昭 51 照学全国大会予稿 61

（受付 1976 年 5 月 11 日）

\section{新製品紹介}

\section{東芝光電池照度計 IM-1}

明るく快適な生活環境を維持する上で，正しい照明管 理が重要な役割を果たしている。ところが，私たちの日 常生活では, 意外之不健全な照明の中で生活をしている ことが多く, 知らず知らずのうちに目や神経が疲れ, 能 率が上がらなかったり，危険だったりする場合が往々に

\section{してある。}

東京光学機械秼では, 法定照度計 (SPA-6A) をはじ め数多くの優れた照度計を世に送り出してきているが, このたび, 照明の重要性をさらに広く認識させるために も, 正しい照度が簡単に測定できる普及形として, 従来 の 7 号形を改良した光電池照度計 IM-1 を開発した.

コンパクトなポケッタプルタイプになっているため, プロの照明設計者や電気工事関係者による照度測定はも ちろん, 事務所, 工場, 学校, 病院などの保守管理に, そして一般家庭でも, 誰もが手軽にどこでも, 簡単に照 度が測定できる特長を持っている。

仕 様

測定範囲 $20 \sim 5,000 \mathrm{~lx}$ ( 2 段切替光)

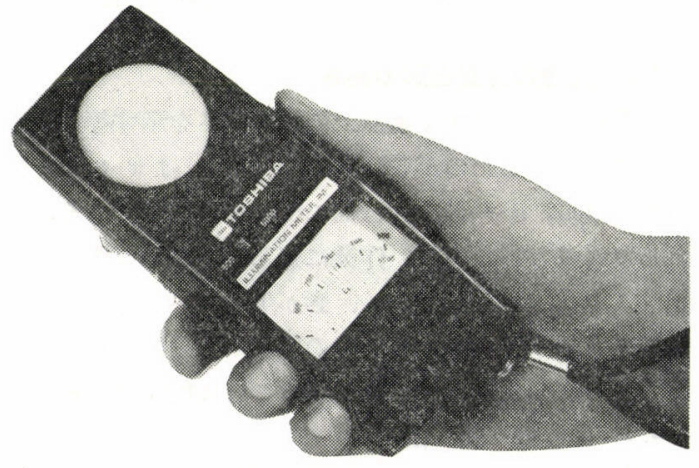

精 度 $\pm 7 \%$ (JIS A 級) (フルスケールに 対し $\tau)$

再現性 $2 \%$ 以内

分光感度 標準比視感度に近似

角特 性 余弦則飞近似

使用条件 温度 $5 \sim 35^{\circ} \mathrm{C}$ 湿度 $45 \sim 85 \%$

外形寸法 $58 \times 151.5 \times 36.3 \mathrm{~mm}$

重 量 $200 \mathrm{~g}$

価格 19,500円

\begin{tabular}{r|c|c}
\hline レン: & $\begin{array}{c}\text { 全目盛の照度 } \\
(\mathrm{lx})\end{array}$ & $\begin{array}{c}\text { 1目盛の照度 } \\
(\mathrm{lx})\end{array}$ \\
\hline 500 & 500 & 20 \\
5,000 & 5,000 & 200 \\
\hline
\end{tabular}

（提供 東芝電材( 